\title{
Evidence of coastal dune mobility increases over the last half century in response to historical human intervention
}

\author{
Marina Navarro-Pons, Juan J. Muñoz-Pérez, Jorge Román-Sierra, Santiago García \\ Andalusian Centre for Maritime Studies, CASEM, University of Cádiz, Río San Pedro s/n, 11510 Puerto Real, Cádiz, \\ Spain.E-mail: juanjose.munoz@uca.es
}

\begin{abstract}
Summary: Given the risk of two roads being buried by the sand of two highly mobile coastal dunes (Valdevaqueros and Bolonia, SW Spain), several measures have been taken over the last half century in order to stabilize them or at least slow their progress: installation of several rows of 1-m-high concrete structures, planting of species such as Pinus pinea, Retama monosperma and Ammophila arenaria, wicker and wooden fencing, and sand mining (only performed on the Valdevaqueros dunefield). The evolution of the two dunes was investigated through the interpretation of intensive topographical monitoring and aerial photography. Average migration rates of approximately $10 \mathrm{~m} \mathrm{yr}^{-1}$ were detected and the burial of anthropic structures has eventually occurred. This process has caused a serious regional problem, making dune management of these areas a difficult challenge. The comparison of the evolution of these two dunes has been of great importance in assessing the effect of historical human intervention and has provided a new perspective for future dune management strategies. The results obtained show that management measures based on sand removal have been proven to be unsustainable. Moreover, the monitoring methodology presented herein has proven very useful in predicting dune advance rates. For instance, the Bolonia dune could reach the nearest road in approximately 12 years.
\end{abstract}

Keywords: coastal dunes, dune mobility; aeolian transport rate; topographic monitoring; aerial photography; dune management; dune evolution.

Evidencias del incremento en la movilidad de dunas costeras en el último medio siglo como respuesta a la intervención humana

Resumen: Se han tomado diferentes medidas a lo largo del último medio siglo tratando de estabilizar o al menos ralentizar el progreso de dos dunas costeras de alta movilidad (Valdevaqueros y Bolonia, SW España) dado el riesgo de enterramiento de sendas carreteras: Entre las medidas tomadas cabe destacar la instalación de filas de estructuras de hormigón de $1 \mathrm{~m}$ de altura, la plantación de diferentes especies (como el Pinus pinea, la Retama monosperma o la Ammophila arenaria), vallas de madera y brezo, y la extracción de arena (sólo en la duna de Valdevaqueros). La evolución de ambas dunas se ha investigado a través de la comparación de levantamientos topográficos y fotografías aéreas. Se han detectado tasas medias de avance de aproximadamente $10 \mathrm{~m} / \mathrm{año}$ hasta que, finalmente, se han enterrado estructuras antrópicas. Este proceso ha causado graves problemas convirtiendo en un difícil reto la gestión de dunas de estas áreas. La comparación de la evolución de estas dos dunas ha resultado de gran importancia a la hora de evaluar el efecto de la intervención humana, y ha proporcionado una nueva perspectiva para las futuras estrategias de gestión. Entre los resultados obtenidos, debería destacarse el que la gestión basada en la retirada de arena ha resultado insostenible. Además, la metodología de seguimiento aquí presentada ha probado ser de gran utilidad al predecir las tasas de avance de las dunas. Por ejemplo, la duna de Bolonia podría alcanzar la carretera próxima en unos 12 años.

Palabras clave: dunas costeras; dunas alta movilidad; tasa de transporte eolico; seguimiento topográfico; gestión costera; evolución dunar.

Citation/Como citar este artículo: Navarro-Pons M., Muñoz-Pérez J.J., Román-Sierra J., García S. 2016. Evidence of coastal dune mobility increases over the last half century in response to historical human intervention. Sci. Mar. 80(2): 261272. doi: http://dx.doi.org/10.3989/scimar.04336.16A

Editor: P. Puig.

Received: August 27, 2015. Accepted: January 20, 2016. Published: March 31, 2016.

Copyright: () 2016 CSIC. This is an open-access article distributed under the Creative Commons Attribution-Non Commercial Lisence (by-nc) Spain 3.0. 


\section{INTRODUCTION}

Coastal dune research has become especially important in recent decades because of the multiplicity of roles played by dunes (shoreline protection, sedimentary balance, ecological functions, landscape singularity, etc.) and the vulnerability arising from their location in the coastal environment (Martínez et al. 2006, Williams and Davies 2001). Furthermore, dune systems are the most efficient and least expensive defence against shoreline erosion (Gómez-Pina et al. 2002) and the consequent risks (del Río 2007).

Many lines of research into these ecosystems are currently focused on the lack of dune mobility. Dune stabilization takes place when the original conditions of dune development are modified because of changes in the vegetation cover or sediment supply or a decrease in migration rates (Jackson and Cooper 2011). However, coastal dunes can be stabilized or remobilized in response to changes in wind power (Levin et al. 2007). Indeed, Yizhaq et al. (2007) and Tsoar et al. (2009) observed that in rainy areas with an environment capable of supporting vegetation cover and a prevalence of intermediate wind speeds, mobile and stabilized dunes can coexist, whereas under lower wind speeds dunes are always fixed. Nevertheless, it should be noted that mature soils do not necessarily have to be geomorphologically inactivity either in coastal or inland areas (Paskoff 2003).

Conversely, in other dune systems the problem lies in the loss of stability and a subsequent increase in mobility. It is assumed that under extremely high wind stress, vegetation is destroyed and dunes are reactivated. Furthermore, it has been shown that long droughts or mega-droughts lead to a reduction in vegetation cover and dune reactivation (Schmeisser et al. 2009, Hanson et al. 2010).

Del Valle et al. (2008) found high migration rates (over $9 \mathrm{~m} \mathrm{yr}^{-1}$ ) in some coastal dunes in Argentine Patagonia. Girardi and Davis (2010) recognized a recent reactivation phase of parabolic dunes in the Walking Dune Field in Napeague (New York) from GPR images. Maia et al. (2005) found that migration rates observed in the dunes of Ceará (Brazil) depended inversely on the size of the dunes, so migration decreased as the size of the dunes increased. Jackson et al. (2013) also determined migration patterns in Gran Canaria by using 1-m resolution LiDAR surveys. However, there are noteworthy cases in Europe, such as the Rubjerg Knude dune in Denmark, where the accumulation of aeolian sand began quite recently (approximately $300 \mathrm{BP}$ ) and the modern high dune only began to form after 1885, apparently in association with an acceleration in the rate of coastal cliff retreat (Saye et al. 2006). In the Pilat littoral dune (France), different phases of dune activity have been identified; the most recent one was believed to have occurred after the planting of pine forests along the French coast in the late $19^{\text {th }}$ century (Tastet and Pontee 1998). These transverse dunes of increasing height that grow landward are mainly formed when there is sparse vegetation cover, abundant sand supply and moder- ate wind power. Another example of a transverse dunefield has recently been identified and studied by Jackson et al. (2014) in northern KwaZulu-Natal (South Africa). Within this transverse dune family, transgressive dune systems are large aeolian sand deposits formed by sand sheets deposited over vegetated or semi-vegetated dunefields. These dunes have two different slopes: moderate on the windward side and steeper on the leeward side (Tsoar et al. 2004). The windward side ends in a practically horizontal dune crest and a leeward slope generally close to the critical angle of repose of sand $\left(34^{\circ}\right.$ to $40^{\circ}$ depending on the humidity).

These dunes often act as major sand sinks and tend to move sand systematically inland, away from the beach and the littoral active zone (Rust and Illenberger 1996). This process may cause the invasion of other adjacent ecosystems, changing the ecological conditions of the invaded site, including shrub species, pine and broom groves, salt marshes (Cooper and McLaughlin 1998), cropland, grassland, and even human settlements (Avis 1989, Bate and Ferguson 1996, Hertling and Lubke 1999, Yao et al. 2007).

Generally, degraded dune ecosystems can be recovered by means of ecological restoration, providing long-term stability. The main goal of restoration is to help the ecosystem to recover its dynamic equilibrium by developing methods and soft technologies such as protective systems (walkways, fencing, signs and communications systems, etc.) and regeneration systems (sand fencing, vegetation plantations, and removal of invasive species), as described by Ley et al. (2011). Therefore, rehabilitation programmes of these systems are currently one of the priorities of coastal managers. One of the latest studies, assessing the efficiency of the recuperation techniques of a foredune system, was carried out by Portz et al. (2015) in Shangri-la (Brazil). Digital terrain models and the sediment volume variation were used in order to discuss the unanticipated alterations due to the interventions carried out. Despite these management tools, some types of invasive dunes make monitoring much more difficult because they are not stabilized systems (Román-Sierra et al. 2004).

Along the Cádiz coast (SW Spain), two of the biggest coastal dunes in southern Europe, the Bolonia and Valdevaqueros dunes, are moving systematically inland. To reduce sand invasion towards rural settlements and other infrastructures, several stabilization and restoration activities have been implemented over recent decades. The persistent growth of the dunes has led to great social pressure, especially in the case of Valdevaqueros. For this reason, before elaborating suitable management strategies, it is necessary to understand more about the development of these dunes. The aim of this paper is to describe and compare the morphodynamic evolution of these transgressive dune systems, taking into account human intervention over the last half century, analysing the different measures performed in an attempt to stabilize them, and extracting conclusions to improve dune management strategies in similar scenarios. 


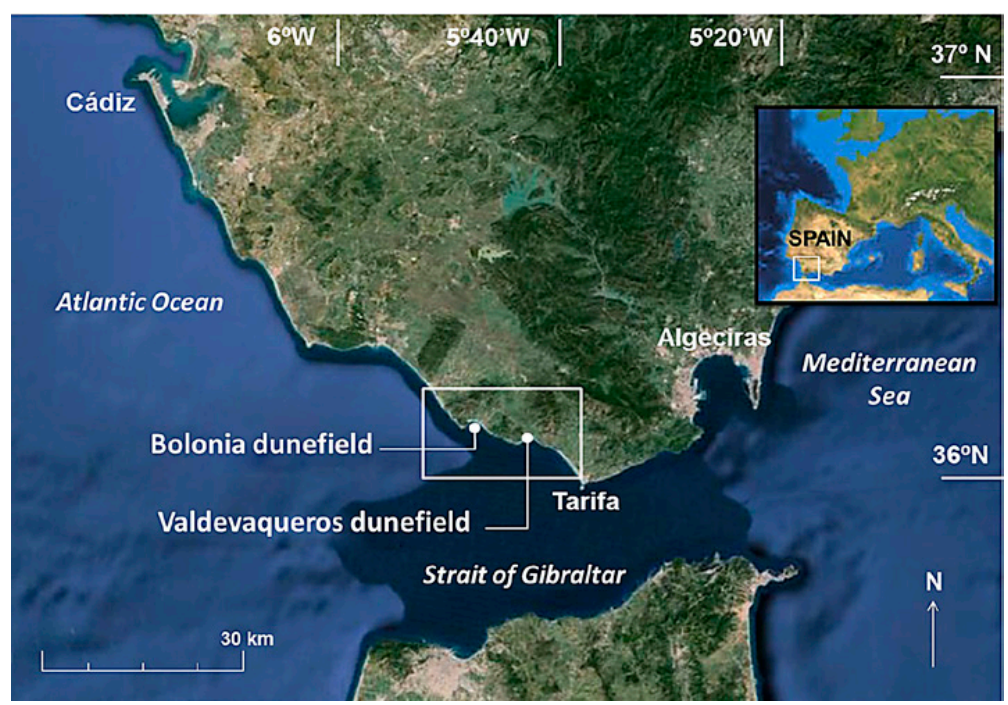

Fig. 1. - Location of the dunefields

\section{STUDY AREA}

\section{Features of the dune environment}

The Bolonia and Valdevaqueros coves are located near the town of Tarifa, on the SW Atlantic coast of Cádiz, $10 \mathrm{~km}$ from the Strait of Gibraltar, at the geographical coordinates $36^{\circ} 9^{\prime} \mathrm{N}$; $5^{\circ} 78^{\prime} \mathrm{W}$ and $36^{\circ} 4^{\prime} \mathrm{N}$; $5^{\circ} 41^{\prime} \mathrm{W}$, respectively (Fig. 1). The shoreline has a NW-SE direction, and according to the classification of Davis and Hayes (1984), the coast has a microtidal environment (Fages et al. 2007, del Río et al. 2012), with a spring tidal range of $1.69 \mathrm{~m}$ and a neap tidal range of $0.5 \mathrm{~m}$ (IHM 2010). The relation between daily variations in sea level and meteorological forcing can be found in Aboitiz et al. (2008).
Both beaches have large transgressive dune systems that were part of an old bypass dunefield (Navarro et al. 2011) that until the mid-twentieth century extended from Valdevaqueros to Bolonia cove and from Bolonia cove to El Cañuelo Beach (Fig. 2). The Bolonia dunefield had an area of approximately 90 ha and was $2800 \mathrm{~m}$ long and 300-400 $\mathrm{m}$ wide, as shown in Fig. 2B. The original Valdevaqueros dunefield had an area of approximately 440 ha (Fig. 2C), with barchan dunes formed at the western end, where sand availability is more limited.

The Cádiz littoral zone, between the Guadalquivir River Mouth and the Strait of Gibraltar, has a steplike morphology conditioned by the existence of two groups of transverse faults whose tectonic directions are NNW-SSE and E-W (Gutiérrez-Mas et al. 1991,
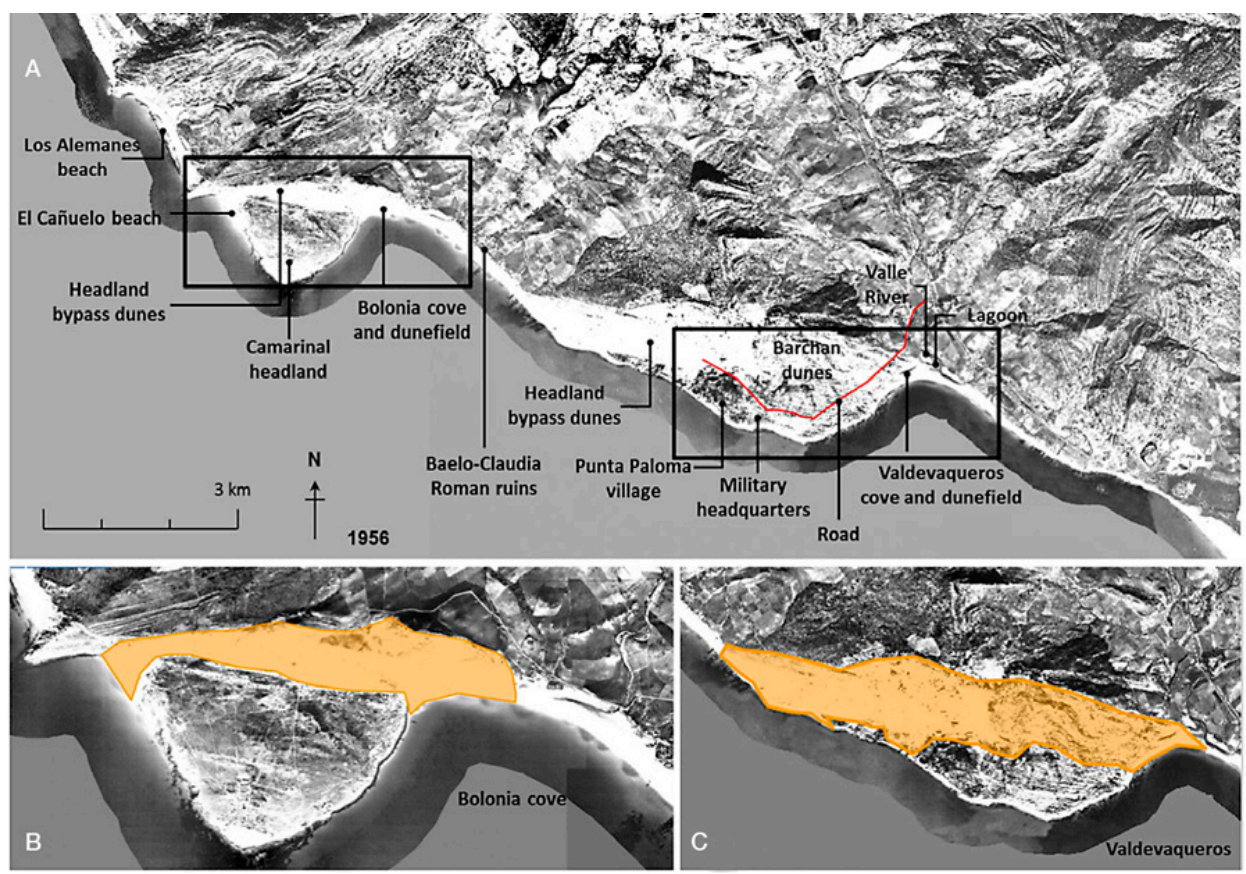

Fig. 2. - A, aerial photograph from the American flight in 1956, where the formation of a former bypass dunefield can be seen from Valdevaqueros to Bolonia. B, area of the Bolonia former bypass dunefield ( 90 ha). C, area of the Valdevaqueros former bypass dunefield (440 ha). 

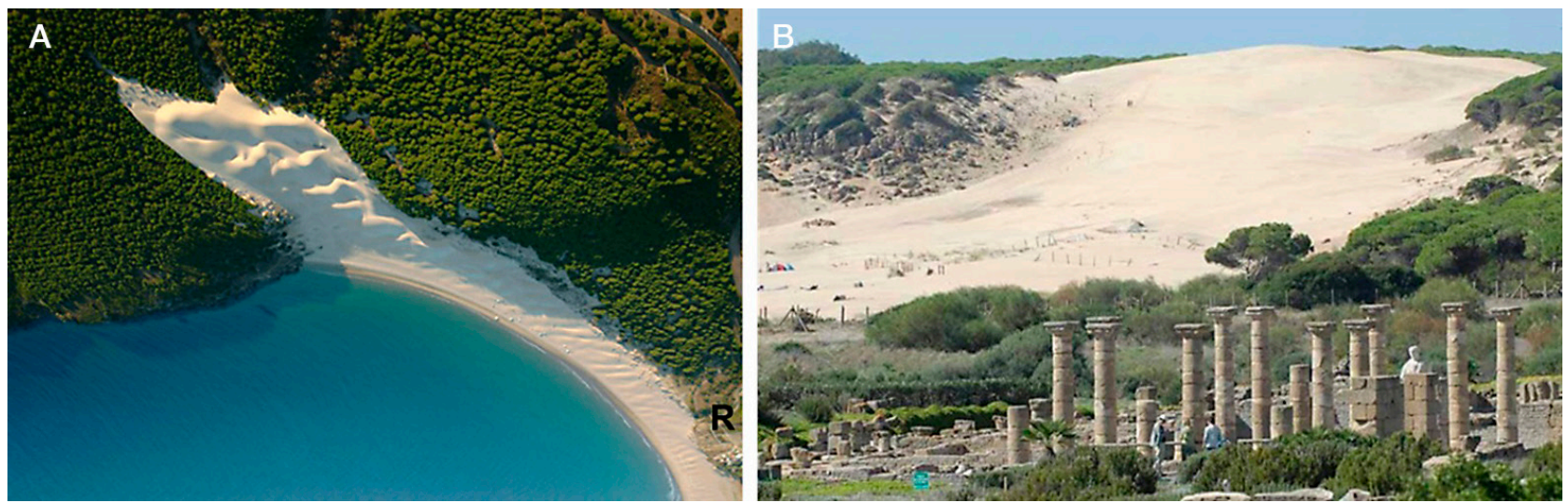

Fig. 3. - A, aerial view of Bolonia beach and dune with the Roman ruins in the right corner (point R). B, view of the Bolonia dunefield from the ruins of Baelo-Claudia.

Gracia and Benavente 2000). This feature causes the deflection of river channels, which act as traps interfering with the littoral drift coming northwards from sand accumulations located south of the zone (MuñozPérez et al. 2009). In particular, Valdevaqueros dune is bounded by the mouth of the Valle River to its east, which forms a small estuary whose position migrates seasonally along the beach as a function of the rainfall climate.

The areas surrounding these dunes are minimally inhabited areas, with the rural communities Punta Paloma (approx. 500 inhabitants) and El Lentiscal (approx. 200 inhabitants) in Valdevaqueros and Bolonia, respectively, including areas of great historical and cultural significance, particularly the Roman ruins of Baelo-Claudia (Fig. 3) close to Bolonia beach (RománSierra et al. 2004), which was presumably destroyed by an earthquake in the 4th century AD (Silva et al. 2005). The Bolonia and Valdevaqueros dune systems form part of the Natural Park of the Strait of Gibraltar, and in addition, the Bolonia dunefield was declared a Natural Monument in 2001 (BOJA 2001).

The wind regime in the Strait of Gibraltar is largely influenced by the surrounding orography, which is 400-800 $\mathrm{m}$ high. As a result of a pressure gradient between the Atlantic Ocean and the Mediterranean Sea, wind accelerates when going through the $20-\mathrm{km}$-wide gap (Dorman et al. 1995), but the wind dynamics in the Strait are complex and are not simply the result of Venturi effects. Maximum wind speed values are not located at the narrowest section of the gap but further to the west, in the area offshore of Bolonia (Capon 2006). For this reason, both dune ecosystems are strongly influenced by the local aeolian regime. Dominant winds come from the east with a lesser SE component, whose average is approximately $60 \mathrm{~km} \mathrm{~h}^{-1}$ (Muñoz-Pérez et al. 2009), with wind gusts that reach $100 \mathrm{~km} \mathrm{~h}^{-1}$ (GómezPina et al. 2002). Westerly winds are also abundant, but with larger directional dispersion and lower speeds. Easterly and westerly winds include more than $90 \%$ of the wind speeds greater than $10 \mathrm{~m} \mathrm{~s}^{-1}$ (Plomaritis et al. 2013). More specific wind information is available at Navarro et al. (2011, 2015).

These strong and frequent wind conditions are ideal conditions for sailing sports such as kiteboarding, which holds its world championship competition each year at Valdevaqueros beach (Fig. 4). Therefore, there is intense pressure from people on the beach and from the proliferation of paths and roads in the area where a foredune could be expected to develop (there is even a car park close to the river mouth). The dune sands have a mean grain size ranging from 0.28 to $0.30 \mathrm{~mm}$, a similar value to that of all the beaches of the Gulf of Cádiz (Navarro 2011). A comprehensive list of the
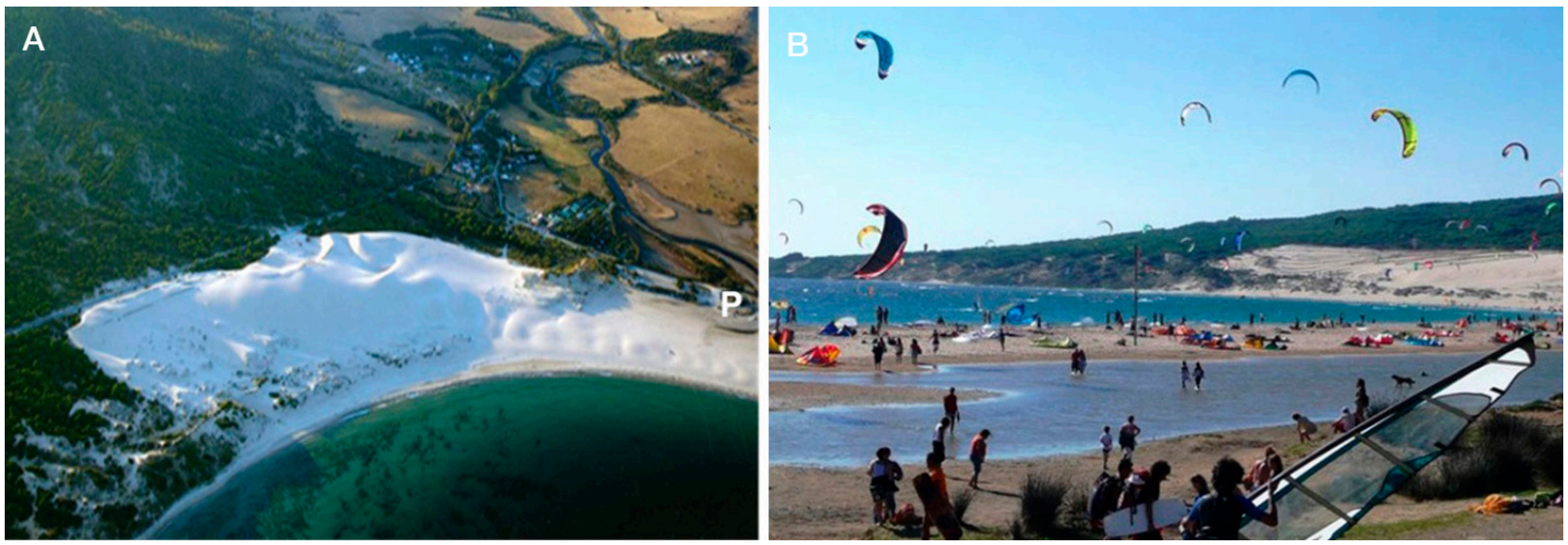

Fig. 4. - A, aerial view of Valdevaqueros beach and dune with the parking lot at its eastern end (point P). B, leisure uses of Valdevaqueros beach with the dune at the bottom. 
Table 1. - Sand mining $\left(\mathrm{m}^{3}\right)$ at the Valdevaqueros dune (updated from Muñoz-Perez et al. 2009).

\begin{tabular}{|c|c|c|c|c|c|c|c|c|c|c|c|c|c|}
\hline Year & Total & Jan & Feb & Mar & Apr & May & Jun & Jul & Ago & Sep & Oct & Nov & Dec \\
\hline 1991 & 76700 & - & - & - & - & 76700 & - & - & - & - & - & - & - \\
\hline 1994 & 174500 & - & - & - & - & - & - & - & - & - & - & - & - \\
\hline 1995 & 12000 & - & - & - & - & - & - & - & - & - & - & - & - \\
\hline 1996 & 15000 & - & - & - & - & - & 5700 & - & - & - & - & - & - \\
\hline 1999 & 85407 & - & - & - & - & - & - & - & - & - & - & - & - \\
\hline 2000 & 66299 & - & - & 15000 & 25000 & 28488 & 16912 & 9387 & - & - & - & - & \\
\hline 2002 & 94787 & - & - & - & - & - & - & - & 3600 & - & - & - & - \\
\hline 2003 & 3600 & - & - & - & - & - & 4387 & 7000 & - & - & - & 4587 & - \\
\hline 2004 & 7000 & - & 4587 & - & - & - & 6750 & - & - & 4700 & 7700 & 7700 & - \\
\hline 2005 & 52031 & - & 8420 & - & - & - & - & - & 15000 & 15000 & - & - & - \\
\hline 2006 & 30000 & - & - & - & - & - & - & - & 15000 & 15000 & - & - & - \\
\hline 2008 & 24300 & - & 5000 & 8750 & 6250 & 6600 & 4500 & 13800 & 3000 & 6000 & 7500 & 25447 & 8435 \\
\hline 2009 & 42500 & 8965 & 9011 & 9687 & 4232 & 42500 & - & - & 15200 & 19596 & - & - & - \\
\hline 2010 & - & - & - & - & - & - & - & - & - & - & - & - & - \\
\hline 2011 & - & - & - & - & - & - & - & - & - & - & - & - & - \\
\hline Total & 684124 & & & & & & & & & & & & \\
\hline
\end{tabular}

average grain sizes of these sands with their sorting, skewness and kurtosis is available in Román-Sierra et al. (2014), and the methodology used to obtain these data is in Román-Sierra et al. (2013).

Both dunefields have experienced very high activity levels during recent decades despite the implementation of several restoration techniques, such as sand fencing and plantations (Ley et al. 2011), and even extensive sand mining. Dune stabilization was intended to reduce the rate of dune front advance towards the pine groves and infrastructure. In the case of Valdevaqueros, the only road that connects to the rural settlement of Punta Paloma is being invaded constantly by dune sands. In contrast to the activities described in Gómez-Pina et al. (2007), which were never criticized, this process is causing a serious local problem that requires strategic coastal management. Similarly, in Bolonia, the advancing dune front is currently located approximately 300 $\mathrm{m}$ from the nearest road, so road invasion may occur in the medium term without mitigation.

\section{Dune stabilization attempts}

To mitigate sand invasion towards anthropic infrastructure, the first interventions carried out during the 1930s consisted of installing several rows of 1-m-high concrete structures. These structures not only did not reduce the dune advance but strongly altered the natural dune profile, as the lack of porosity did not provide for natural aeolian sand accumulation and therefore

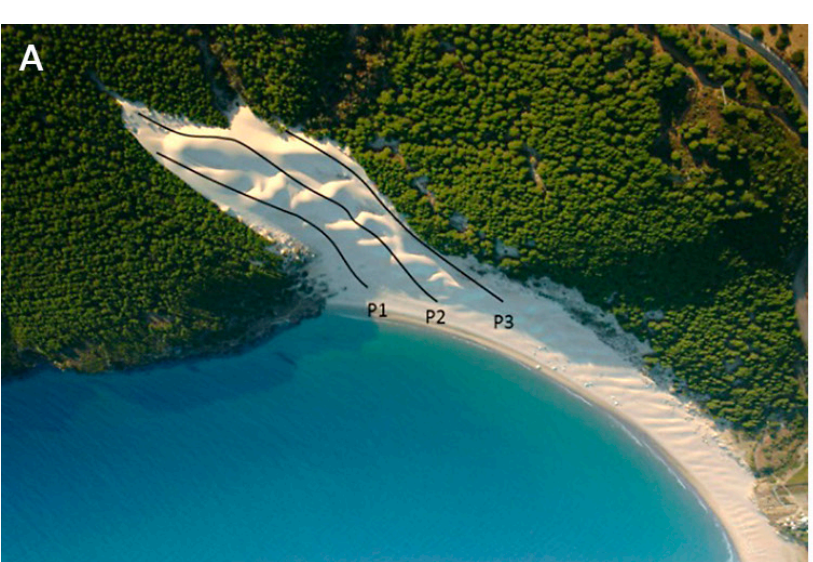

prevented the development of vegetation. Indeed, subsequent studies demonstrated that the optimum porosity of sand fences should be approximately $50 \%$ (a detailed literature review on the efficiency of sand stabilization systems can be found in Willetts and Phillips 1978).

The Valdevaqueros and Bolonia dunefields were artificially fixed approximately in 1946 and 1953, respectively, by species such as Pinus pinea, Eucalyptus sp. and Retama monosperma (Gracia et al. 2011). Pine grove plantations near Bolonia covered the Camarinal headland, which is approximately $2.5 \mathrm{~km}$ long and $300 \mathrm{~m}$ wide, reaching the Baelo-Claudia Ruins (to the east), and similarly, the Valdevaqueros pine grove was planted from the eastern part of Bolonia beach to the Valdevaqueros cove (see Fig. 2). In addition, restoration activities were employed for the first time between 1961 and 1962 by means of wattle fences and, subsequently, wicker and wooden fencing. After every wind storm, the fences were renewed manually, as they were quickly covered by the sand.

From that point forward, dune growth was only limited by periodic sand extraction by individuals for construction use. Since the enactment of the Spanish Shore Act (BOE 1988), which banned dune sand mining for private profit, the Ministry of Environment decided that the best solution was to relocate large volumes of dune sand from Valdevaqueros to other beaches (Muñoz-Pérez et al. 2014) in addition to continuous sand fencing. Table 1 shows sand mining

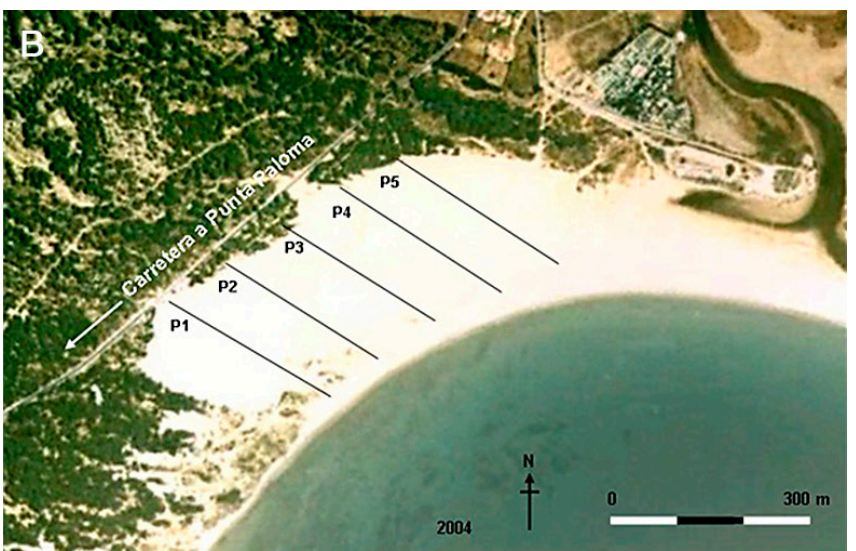

Fig. 5. - Collected dune profiles at the Bolonia (A) and Valdevaqueros (B) dunefields. Pine groves were planted in the mid-20th century. 
volumes removed by the Coastal Department, totalling more than $684000 \mathrm{~m}^{3}$ in 20 years of extraction activity (updated from Muñoz-Pérez et al. 2009). When the dune front reached the road in Valdevaqueros in 2004, sand extraction increased to prevent the road from being buried. Marram grass (Ammophila arenaria) has also been planted, especially during the last decade.

In spite of all of the human stabilization attempts, both dune systems have grown in an uncontrolled manner over the pine groves located on their leeward sides (Fig. 5), showing the difficulty of dealing with a highly active dune (Gracia et al. 2013).

\section{METHODS}

To investigate the morphological evolution and advance of the Bolonia and Valdevaqueros dunefields, several topographic surveys were performed using differential global positioning system (DGPS) techniques and total station theodolites. The DGPS can provide accuracy to the centimetre for carrier phase tracking (usually less than $10 \mathrm{~cm}$ ), consistent with the methodology followed by Rodríguez-Santalla et al. (2009).

On the other hand, the methodology related to the contribution of the principal statistical parameters (mean grain size, sorting, skewness and kurtosis) presented by other authors (e.g. Alcántara-Carrió and Alonso 2001, Alcántara-Carrió et al. 2010) has not been followed in this paper because the sand parameters are almost identical at Bolonia and Valdevaqueros. Interested readers may turn to Navarro et al. (2015) for data obtained in these dunes.

At the Bolonia dunefield, two topographical campaigns were carried out, in 2008 and 2011 (Fig. 5). Three longitudinal profiles in the direction of dune movement were surveyed in each campaign. At the Valdevaqueros dunefield, 11 campaigns were performed from 1995 to 2009 , each one comprising 5 dune profiles.

In addition, aerial photos from 1956, 1974, 1979, 1985, 1990, 1998, 2002, 2005, 2008 and 2011 for Bolonia and photos from 1956, 1974, 1979, 1985, 1998, 2001, 2004, 2006, 2008 and 2011 for Valdevaqueros were used for dune monitoring. Most of the aerial photographs are vertical (e.g. the photos of 1956, scale 1: 9100 and of 1990, scale 1: 5000, available from the Army Geographical Service and the Directorate General of Coasts, respectively). Other photographs are orthorectified projections and properly georeferenced (e.g. year 1998 and scale 1:60000) and can be downloaded from the Junta de Andalucia webpage (http://www.juntadeandalucia.es/medioambiente/site/ rediam/).

Dune front activity was determined by the use of the OGC Generic Viewer of the Environmental Network of Andalusia (south Spain) and GRAPHER software for mapping. A percentage of minimum error was assumed during the interpretation of the available cartography (del Río and Gracia 2013). The methodology can be found at Domínguez et al. (2004). Finally, a very interesting study of the historical evolution of the Valdevaqueros dune, including ancient topographical

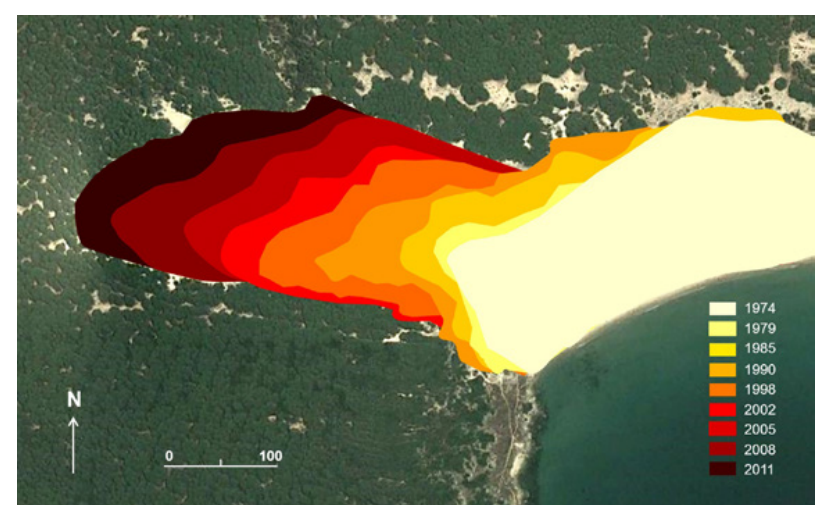

Fig. 6. - Evolution of the Bolonia dunefield from 1974 to 2011.

maps (1917 and 1955), can be consulted (Bello-Millán et al. 2015).

\section{RESULTS}

Due to their particular geographical location and the strong and frequent easterly winds that produce mass aeolian transport from the dry beach to the dune crest, the Bolonia and Valdevaqueros dune systems have experienced substantial growth in the last 50 years.

\section{Bolonia dunefield evolution}

Figure 6 shows the Bolonia dune's evolution from 1974 to 2011, revealing an average total advance of $320 \mathrm{~m}$ in 37 years. At least two dune fronts have been identified since 1985. The most active front closely matches the surveyed western profile (B1). Since 1990, the dune area seems to have increased but narrowed at the same time, occupying the corridor bottom between Bolonia and Cañuelo. Despite the increasingly vertical climb of dune development, the fastest dune advance was experienced during the last six years of the research period.

Topographical observations reveal that the Bolonia dune profiles experienced a great accretion during the final three years of the research period (i.e. 20082011). As an example, the topographical evolution of the western profile of Bolonia (B1) can be observed in Figure 7 . The dune elevation changes depending on the dune profile, with a maximum height above the datum

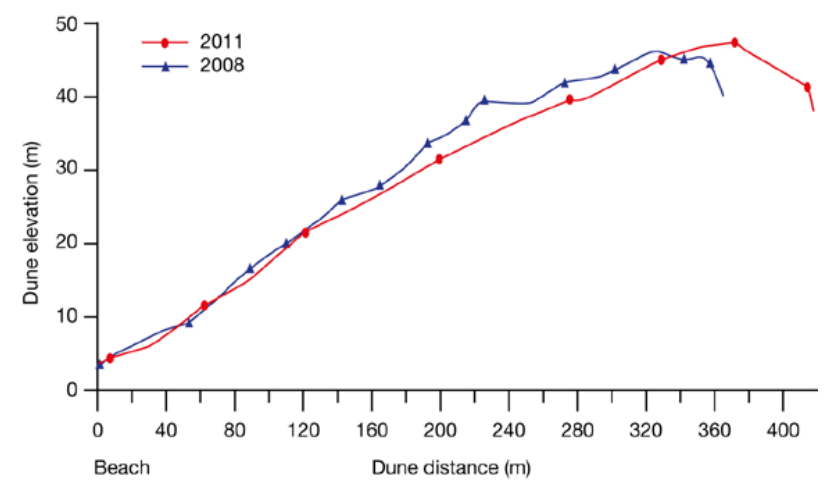

Fig. 7. - Topographic evolution of the Bolonia dune profile (B1) from 2008 to 2011 . 


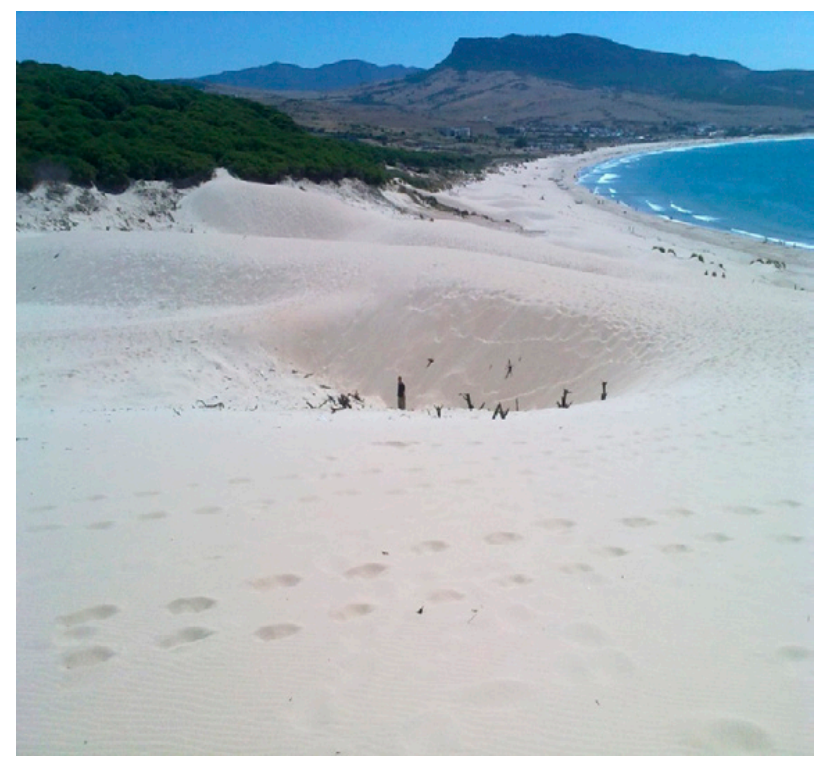

Fig. 8. - Deflation basins in the Bolonia dune. Note: A person is shown for scale.

(the lowest low water level, LLWL) of approximately $47 \mathrm{~m}$ in profiles $\mathrm{B} 1$ and $\mathrm{B} 3$ and $50 \mathrm{~m}$ in profile $\mathrm{B} 2$. The average elevation change was of the order of $1.10 \mathrm{~m}$ $\mathrm{yr}^{-1}$ from 2008 to 2011.

The Bolonia dune has adopted irregular morphologies along the windward face, creating deflation basins, which are depressions that appear in the central area of the dunefield and have height differences of up to $10 \mathrm{~m}$ with barely $20 \mathrm{~m}$ of horizontal displacement (Fig. 8). The dune area and advance rates derived from the analysis of the Bolonia dune images are shown in Table 2, in which it is possible to identify the evolution of the western and eastern dune profiles (B1 and B3), with a total advance ranging from 284 to $356 \mathrm{~m}$ in almost 40 years.

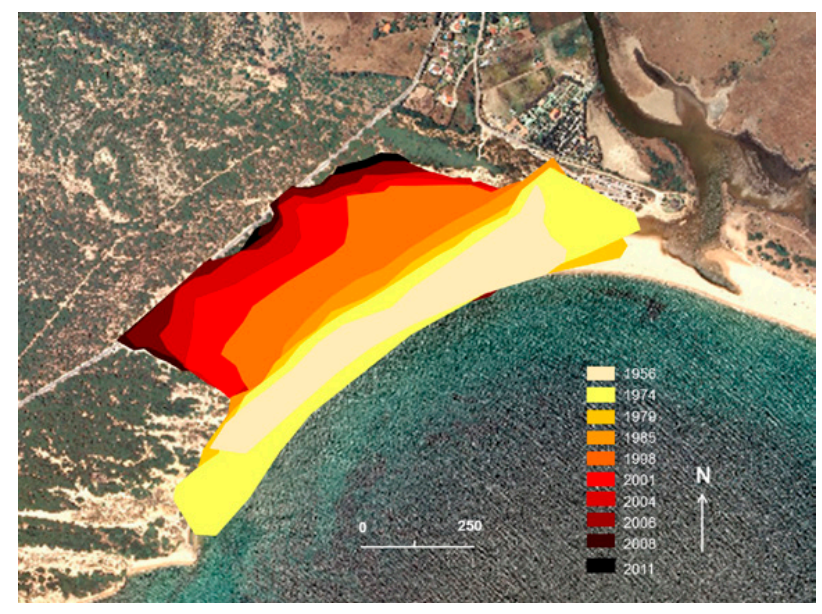

Fig. 9. - Evolution of the Valdevaqueros dunefield from 1974 to 2011

\section{Valdevaqueros dune evolution}

The Valdevaqueros dunefield has been subjected to many more interventions than Bolonia to mitigate sand advance towards the adjacent road. Figure 9 shows the evolution of the Valdevaqueros dunefield from 1956 to 2011, with a total advance of nearly $300 \mathrm{~m}$ in 55 years (Table 3).

It is noteworthy that, in addition to its dune profile development, Valdevaqueros beach has also undergone changes in relatively short periods, such as from 1956 to 1974 (accretion) and from 1974 to 1979 (erosion). From 1985 to 1998 , there was a major dune advance ranging from approximately 125 to $200 \mathrm{~m}$, depending on the dune profile. Since 2004, the dune area has remained practically constant due to frequent sand mining (Table 1).

The evolution of the most active profile of the Valdevaqueros dune was monitored topographically from 1995 to 2009, as shown in Figure 10. This pro-

Table 2. - Dune area and advance rates for Bolonia profiles B1 and B3 from 1974 to 2011.

\begin{tabular}{|c|c|c|c|c|c|c|}
\hline \multirow{2}{*}{ Date } & \multirow{2}{*}{$\begin{array}{c}\text { Dune area } \\
\left(10^{4} \mathrm{~m}^{2}\right)\end{array}$} & \multirow{2}{*}{$\begin{array}{l}\text { Increase rate } \\
\left(10^{4} \mathrm{~m}^{2} \mathrm{yr}^{-1}\right)\end{array}$} & \multicolumn{2}{|c|}{ Advance (m) } & \multicolumn{2}{|c|}{ Accumulated advance (m) } \\
\hline & & & B1 & B3 & B1 & B3 \\
\hline 1974 & 3.1 & - & - & - & - & - \\
\hline 1979 & 3.7 & 0.1 & 15.6 & 21.9 & 15.6 & 21.9 \\
\hline 1985 & 4.3 & 0.1 & 31.3 & 28.1 & 46.9 & 50.0 \\
\hline 1990 & 4.9 & 0.1 & 81.3 & 28.1 & 128.1 & 78.1 \\
\hline 1998 & 5.4 & 0.1 & 50.0 & 46.9 & 178.1 & 125.0 \\
\hline 2002 & 5.9 & 0.1 & 37.5 & 46.9 & 215.6 & 171.9 \\
\hline 2005 & 6.3 & 0.1 & 37.5 & 31.3 & 253.1 & 203.1 \\
\hline 2008 & 7.2 & 0.3 & 68.8 & 40.6 & 321.9 & 243.8 \\
\hline 2011 & 7.9 & 0.2 & 34.4 & 40.6 & 356.3 & 284.4 \\
\hline
\end{tabular}

Table 3. - Dune area and advance rates for Valdevaqueros profiles V1 and V5 from 1956 to 2011.

\begin{tabular}{|c|c|c|c|c|c|c|}
\hline \multirow{2}{*}{ Date } & \multirow{2}{*}{$\begin{array}{c}\text { Dune area } \\
\left(10^{4} \mathrm{~m}^{2}\right)\end{array}$} & \multirow{2}{*}{$\begin{array}{l}\text { Increase rate } \\
\left(10^{4} \mathrm{~m}^{2} \mathrm{yr}^{-1}\right)\end{array}$} & \multicolumn{2}{|c|}{ Advance (m) } & \multicolumn{2}{|c|}{ Accumulated advance (m) } \\
\hline & & & V1 & V5 & V1 & V5 \\
\hline 1956 & 3.3 & - & - & - & - & - \\
\hline 1974 & 3.5 & 0.0 & 6 & 21 & 6 & 21 \\
\hline 1979 & 4.9 & 0.3 & 14 & 19 & 20 & 40 \\
\hline 1985 & 6.1 & 0.2 & 10 & 67 & 30 & 107 \\
\hline 1998 & 10.2 & 0.3 & 87 & 92 & 117 & 199 \\
\hline 2001 & 14.9 & 1.6 & 75 & 12 & 192 & 211 \\
\hline 2004 & 17.4 & 0.8 & 67 & 2 & 259 & 213 \\
\hline 2006 & 19.9 & 1.3 & 9 & 23 & 268 & 236 \\
\hline 2008 & 21.6 & 0.8 & 0 & 20 & 268 & 256 \\
\hline 2011 & 21.8 & 0.1 & 0 & 9 & 268 & 256 \\
\hline
\end{tabular}




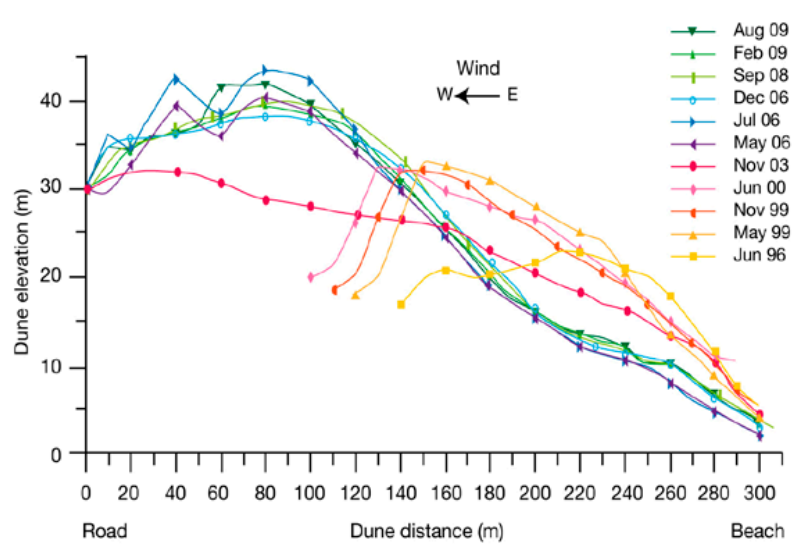

Fig. 10. - Topographic evolution of Valdevaqueros dune profile (V1) from 1995 to 2009.

file (V1) is located in the western part of the dunefield. The dune profile height increased from 24 to 42 $\mathrm{m}$ (an average elevation change of $1.29 \mathrm{~m} \mathrm{yr}^{-1}$ ), and horizontal displacement was $130 \mathrm{~m}$ in only 14 years (average advance rate of $9.28 \mathrm{~m} \mathrm{yr}^{-1}$ ). Therefore, the Valdevaqueros dune profile experienced substantial changes not only in area but also in shape.

The dune profile describes a shifting behaviour during three periods. The first period, from 1995 to 2000, which is considered as the "initial" profile, shows a uniform and progressive accretion of $480 \mathrm{~m}^{3} \mathrm{~m}^{-1} \mathrm{yr}^{-1}$ (Muñoz-Pérez et al. 2009), in which orography plays a very important role. In this stage, the windward side of the dune had a more convex slope, becoming sharper as the dune profile was softened by mechanical action just before 2003. This action, in which the dune was reshaped by distributing the sand from the crest along the stoss slope (and the slipface), did not respect the natural slope angles of the dune. From the moment of this development, the windward face probably acted as a launching ramp from which sand grains were easily transported towards the crest. As a consequence, blown sands were kept away from the dune-beach system interaction. Dune elevation also obviously increased in proximity to the sand fencing, and after the sand reached the road in 2004, the dune experienced shifting morphologies (not only on the crest but also on the windward and leeward sides), resulting in a more complex profile. During the second period (2003 to 2008), the profile continued increasing in height and started to adopt sharp, irregular morphologies, possibly due to the wooden fencing at the dune crest. From May to December 2006, the profile underwent an annual accretion rate of $438 \mathrm{~m}^{3} \mathrm{~m}^{-1} \mathrm{yr}^{-1}$. Finally, during the last phase of dune growth (from September 2008 to August 2009) the dune profile decreased in height, undergoing a net accretion (deducting sand extraction volumes) of approximately $280 \mathrm{~m}^{3} \mathrm{~m}^{-1} \mathrm{yr}^{-1}$.

Based on observations of the dune behaviour in recent years, an average advance rate of profile V1 was calculated as $17.5 \mathrm{~m} \mathrm{yr}^{-1}$ (Muñoz-Pérez et al. 2009). In addition, after considering the "natural" transport rate experienced by profile V1 (taking into account the extracted sand volume and the remaining natural dune volume), it was concluded that only 2-3 weeks of

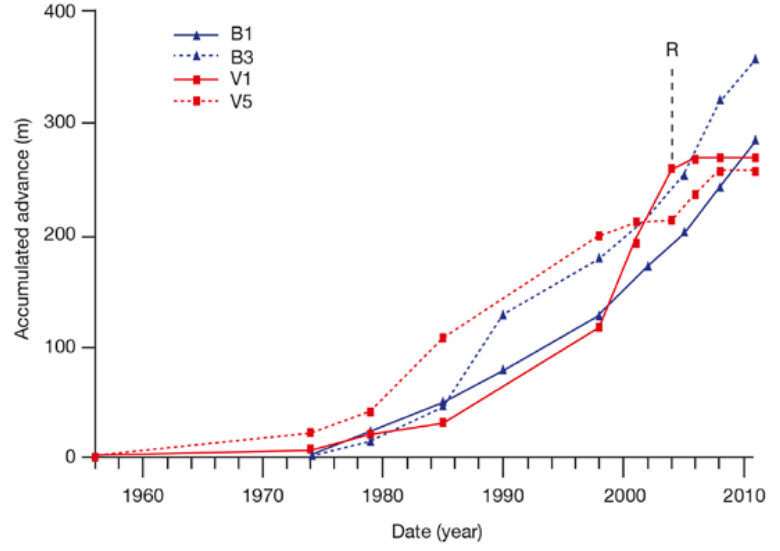

Fig. 11. - Accumulated dune advance for Bolonia profiles (B1 and B3) and Valdevaqueros profiles (V1 and V5) during the study period (1956-2011). R, Point at which profile V1 reached the road.

moderate easterly winds (of approximately $40 \mathrm{~km} \mathrm{~h}^{-1}$ ) would be required to move as much sand volume as during one of the prior years.

Current sand transport rates are one order of magnitude greater than reported in other studies (as Serra et al. 1997 or Cabrera and Alonso 2010). This finding could be explained by the singularity of the strong and frequent wind regime that occurs close to the Strait of Gibraltar. This information is crucial for dune management decision-making. In this case, the current strategy based on the physiographic profile reshaping by mobilization of dune sands from the dune front to the dune foot has proven to be no longer sustainable.

As a result, the Valdevaqueros dune showed very high mobility, especially during the final 14 years of the study period. The dune area accumulated a total net volume of approximately $2000 \mathrm{~m}^{3} \mathrm{~m}^{-1}$ during these 14 years, i.e. approx. $142 \mathrm{~m}^{3} \mathrm{~m}^{-1} \mathrm{yr}^{-1}$, comparable to the volume extracted per year, except from 2003 to May 2006, when the natural dune accumulation exceeded the sand mining volume.

\section{Comparison of Bolonia and Valdevaqueros dune evolution}

As seen in Figure 11, the western end of the Valdevaqueros dune (V1) experienced the highest advance in this dune during the 50-year study period (19562006). This profile has followed a generally exponential advance, which can be split into three phases: The first phase, with a soft slope, is due to the existence of a single foredune near the backshore of the beach. Continuous and imprecise sand mining was carried out during this phase (1956-1985). During the second phase (1985-1998), a higher advance rate was identified, clearly accentuated by the enactment of the Spanish Shore Act (BOE 1988), according to which dune sand extraction for private profit was forbidden as a management tool for beach and dune system conservation. A critical dune profile advance phase was evident from 1998 to 2004, when profile V1 eventually reached the road and was urgently halted by sand extraction and profile reshaping by the Coastal Authority to address the social implications. 

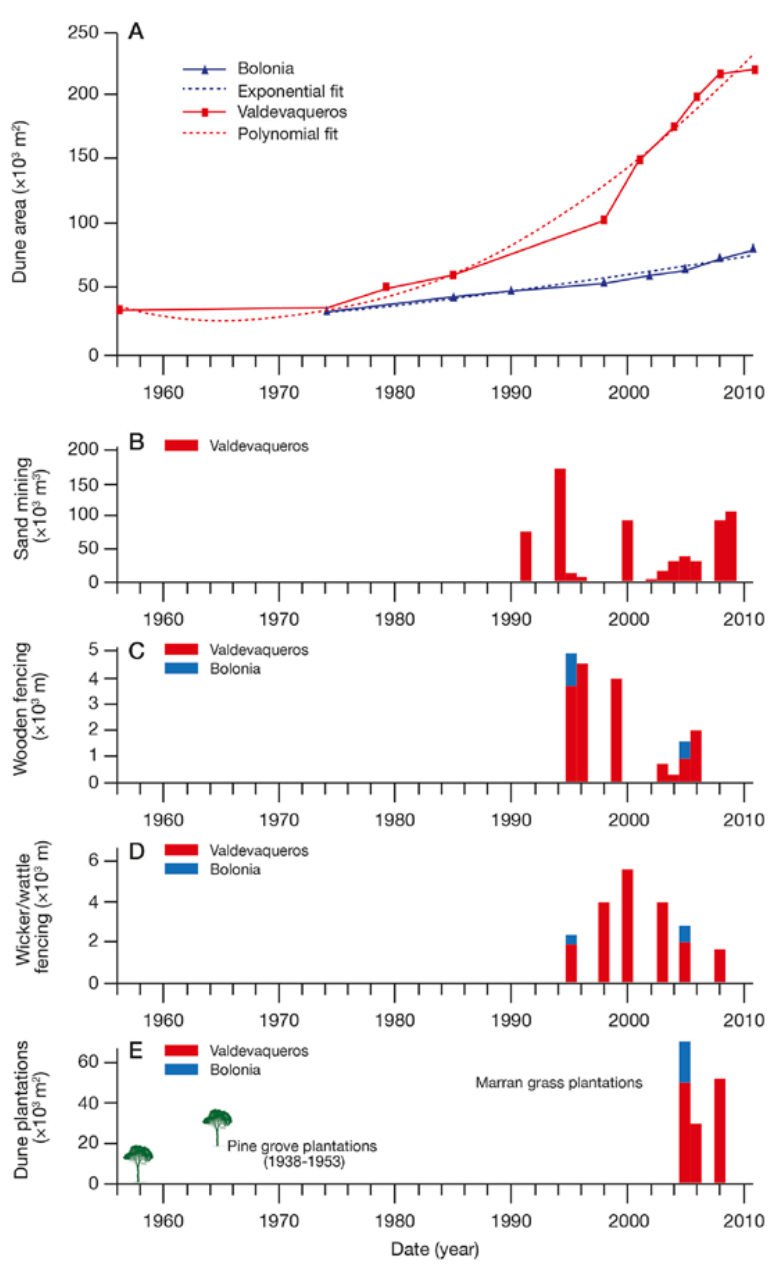

Fig. 12. - A, dune area evolution for Bolonia and Valdevaqueros during the research period (1956-2011). B, sand mining activities. $\mathrm{C}$, wooden fencing. D, Wicker or wattle fencing. E, dune plantation.

The eastern end of the Valdevaqueros dune (V5) also showed similar advance rates but its growth was not as fast and the advance was progressively linear (Fig. 11). Note that sand extraction was not carried out on this part of the dune, although other management tools, such as sand fencing and the planting of vegetation, were employed (Fig. 12) on the windward dune face. In addition, blowing sands are transported westward approximately $75 \%$ of the time during which easterly winds blow (Navarro et al. 2011), as in the profile V1 advance.

The western end of the Bolonia dune (B1) has undergone two slightly different phases (Fig. 12). During the first, from 1974 to 1998 , the profile describes a linear advance, and from 1998 to 2011, it grows exponentially. This climbing dune was most likely influenced primarily by orographic features, as there was no sand mining and few restoration activities. Therefore, because of these orographic features and despite the aeolian sand transport following an E-W direction, the eastern end of the Bolonia dune (B3) underwent higher advance rates from 1985 to 1990 and from 2001 to 2011 .

As shown in Table 4, the Bolonia and Valdevaqueros western profiles (B1 and V1) generally move faster
Table 4. - Advance rates $\left(\mathrm{m} \mathrm{yr}^{-1}\right)$ for the Bolonia and Valdevaqueros western and eastern profiles from 1974 to 2011.

\begin{tabular}{ccccc}
\hline \multirow{2}{*}{ Date } & \multicolumn{2}{c}{ Bolonia } & \multicolumn{2}{c}{ Valdevaqueros } \\
& B1 & B3 & V1 & V5 \\
\hline 1974 & - & - & 0.3 & 1.2 \\
1979 & 3.1 & 4.4 & 2.8 & 3.8 \\
1985 & 5.2 & 4.7 & 1.7 & 11.2 \\
1990 & 16.3 & 5.6 & 6.7 & 7.1 \\
1998 & 6.3 & 5.9 & 25.0 & 4.0 \\
2002 & 9.4 & 11.7 & 22.3 & 0.7 \\
2005 & 12.5 & 10.4 & 4.5 & 11.5 \\
2008 & 22.9 & 13.5 & - & 10.0 \\
2011 & 11.5 & 13.5 & - & 3.0 \\
Average & 10.9 & 8.7 & 9.0 & 6.2 \\
\hline
\end{tabular}

than the eastern profiles (B3 and V5), undergoing higher average advance rates of 10.9 and $9 \mathrm{~m} \mathrm{yr}^{-1}$, respectively. This finding is reasonable considering that the resultant drift direction from wind in these areas is essentially E-W (Navarro et al. 2011).

The advance rates in the Bolonia and Valdevaqueros dunes were at first glance quite variable, both spatially and temporally. In the case of Valdevaqueros, the advance rates were highly influenced by sand mining, especially around the western profile (V1), which has quite variable values, depending on the date. Despite the anthropic interventions, the average advance rates ranged from 6.2 to $9 \mathrm{~m} \mathrm{yr}^{-1}$ for $\mathrm{V} 1$ and $\mathrm{V} 5$, respectively, although maximum values of $25 \mathrm{~m} \mathrm{yr}^{-1}$ were identified in V1. Similarly, the western profile of Bolonia (B1) showed a significant increase in advance rate during the last six years of the research period, reaching maximum values of $22.9 \mathrm{~m} \mathrm{yr}^{-1}$, with an average advance rate of $10.9 \mathrm{~m} \mathrm{yr}^{-1}$ from 1974 to 2011 (see Table 3), whereas the eastern part of the Bolonia dune system (B3) showed maximum values of $13.5 \mathrm{~m} \mathrm{yr}^{-1}$ and an average advance rate of $8.7 \mathrm{~m} \mathrm{yr}^{-1}$. Extrapolating these results, the Bolonia dune could reach the nearest road in approximately 12 years. Thus, monitoring these dunes is highly useful for predicting dune behaviour and estimating dune advance rates in order to adopt preventive measures.

According to Figure 12A, the Bolonia dune area increased from $3.110^{4} \mathrm{~m}^{2}$ to $7.910^{4} \mathrm{~m}^{2}$ between 1974 and 2011. Valdevaqueros has experienced an exponential area increase since 1956, when its delimited area $\left(3.310^{4} \mathrm{~m}^{2}\right)$ was similar to the initial Bolonia dune area (the final area of the Valdevaqueros dune in 2011 was $21.810^{4} \mathrm{~m}^{2}$ ). In terms of dune area increase (Fig. 12B), Bolonia has followed a single linear distribution with a slope of $0.11710^{4} \mathrm{~m}^{2} \mathrm{yr}^{-1}$, whereas Valdevaqueros has shown different phases with three linear distributions: from 1956 to 1974 (rate of $0.01410^{4} \mathrm{~m}^{2} \mathrm{yr}^{-1}$ ), from 1974 to 1998 (rate of $0.27610^{4} \mathrm{~m}^{2} \mathrm{yr}^{-1}$ ) and from 1998 to 2008 (rate of $1.1210^{4} \mathrm{~m}^{2} \mathrm{yr}^{-1}$, coefficients of determination $\left(\mathrm{R}^{2}\right)$ ranging from 0.96 to 0.99$)$.

\section{DISCUSSION}

The advance rate values of both dunes, previously presented, are similar to those identified at the barchans of Jericoacoara (NE Brazil), with values ranging from 14.6 to $21 \mathrm{~m} \mathrm{yr}^{-1}$ (Jiménez et al. 1999). However, at Ceará, the migration of dune fields was calculated 
as approximately $6 \mathrm{~m} \mathrm{yr}^{-1}$ despite being caused by the effects of the climatic phenomenon of El Niño (Maia et al. 2005). In general, advance rates of several metres per year are characteristic of transgressive dune systems. According to Rust and Illenberger (1996), these individual dunefields are so dynamic that they often show shifting behaviours not only in their shape but also in their location, depending on the wind regime.

During the initial phase, the artificial dune stabilization at Bolonia and Valdevaqueros had a twofold effect: the reduction of sand supply inland was achieved, but a slow shoreline advance started as a result of the increasing dune elevation and the steeper windward slope, producing higher sand sedimentation at the dune foot and the backshore.

Sand extraction was performed as the dune grew, to mitigate the sand invading the road, which occurred more frequently during the most recently researched years. Wooden and wicker fencing was the tool most widely used for dune stabilization. However, at Bolonia, fencing was almost experimental in nature, only working in isolated cases. Wooden fences were mainly located on the dune crest, whereas wicker and wattle fencing was employed on the windward side. As a result, the dune morphology developed accordingly. Whereas wicker and wattle fencing provide a more natural and stable profile (due to a higher fence porosity), wooden fencing increases dune elevation, creating a more artificial profile. Moreover, marram grass (Ammophila arenaria) was planted manually during a few experimental episodes, always on the windward foot. This intervention usually produced unsuccessful results, except for the plantations located on the eastern part of the dune, where aeolian sedimentation was not so intensive.

In the case of the Valdevaqueros dune, it is obvious that human activities on the beach-dune area have caused a great alteration of the ecosystem, especially during recent decades. However, changes in the Valle River mouth and its seasonal lagoon, the frequency of river flooding, and the construction of the car park prior to the enactment of the Spanish Shore Act (BOE 1988) might also have strongly influenced dune system development and growth in terms of sediment balance. Thus, the location of the shoreline, the water table and other features proximal to the research area must have caused important changes in sediment availability since 1956.

As the Bolonia dunefield was considered a Natural Monument in 2001 and anthropic interventions have been completely stopped since then, it is considered to have developed more naturally than the Valdevaqueros dune. However, in both cases, unlimited sand availability still seems to represent a serious risk for the uncontrolled advance and growth of the dune.

In brief, the Bolonia and Valdevaqueros dunefields have undergone great transformation since 1956, showing average advance rates of 10.9 and $9.0 \mathrm{~m} \mathrm{yr}^{-1}$ and maximum values of 23 and $25 \mathrm{~m} \mathrm{yr}^{-1}$ for the most active profiles, respectively. Though the two dunes have similar features and wind velocity regimes due to their proximity to the Strait of Gibraltar, the Valdevaqueros dune has experienced more change during the overall research period than the Bolonia dune, mainly caused by sand mining activities. Whereas the Bolonia dune area has always increased linearly $\left(0.11710^{4} \mathrm{~m}^{2} \mathrm{yr}^{-1}\right)$, Valdevaqueros has had a more pronounced tendency to increase over time, at a rate twice this value from 1974 to 1998 , and ten times this value from 1998 to 2008 . Though the Bolonia dune has not undergone so much human intervention as Valdevaqueros (only marram grass plantations and sand fencing in isolated cases), both dune profiles have grown not only in width (two advance fronts have been identified) but also in height, with average elevation change rates of $1.10 \mathrm{~m} \mathrm{yr}^{-1}$ for Bolonia and $1.29 \mathrm{~m} \mathrm{yr}^{-1}$ for Valdevaqueros. These results show that in addition to sand transport generated by wind-blown sand availability, which is similar for both systems, sand distribution is also strongly linked to orography, creating specific morphologies of different heights. It might be argued that these results could also be due to the closer proximity of Valdevaqueros to the Strait of Gibraltar. Unfortunately, although it would provide very interesting outcomes, simultaneous data in both dunes have never been surveyed.

After analysing attempts to mitigate road invasion by blowing sands, some practical and useful conclusions can be established:

- Pine grove plantations did not reduce aeolian sand transport at all and therefore should not be considered an effective method for dune stabilization.

- Sand fencing and marram grass plantations (later management activities), have produced only occasionally successful results due to the massive aeolian sand transport westward.

- Wooden fencing has strongly modified the profile morphology, especially on the Valdevaqueros dune crest, by increasing its height and producing steeper slopes, therefore reducing its stability and giving it a more complex profile. The relationship between this artificial profile and the increase of the migration rate of the dune has not been demonstrated but this possibility should not be excluded.

Thus, as sand supply has never been a limiting factor (Bello-Millán et al. 2015), taking into account that the Valdevaqueros dunefield has developed despite sand extraction in recent decades, given the current profile of the dune, it seems that only 2-3 weeks of moderate easterly winds can produce a sand transport, as happened over a full year when no human intervention took place. As a conclusion, current management measures based on sand removal (which do not respect the natural dune profile) are no longer sustainable.

Moreover, some of the results obtained from this research (such as the fact that the Bolonia dune could reach the nearest road in approximately 12 years) are very useful for conceiving or developing solutions in advance (a summary of the different solutions studied until now is available in Gracia et al. 2013). Therefore, it is extremely important to understand the dynamics of dune development based on historical anthropic intervention in addition to accounting for the special environmental characteristics within the entire physiographic unit when designing future management strategies. 


\section{REFERENCES}

Aboitiz A., Tejedor B., Muñoz-Pérez J.J., et al. 2008. Relation between daily variations in sea level and meteorological forcing in Sancti Petri Channel (SW Spain). Cienc. Mar. 34(4): 491-501.

Alcántara-Carrió J., Alonso I. 2001. Aeolian sediment availability in coastal areas defined from sedimentary parameters. Application to a case study in Fuerteventura. Sci. Mar. 65(S1): 7-20.

Alcántara-Carrió J., Fernández S., Alonso I. 2010. Source area determination of aeolian sediments at Jandia Isthmus (Fuerteventura, Canary Islands). J. Mar. Syst. 80: 219-234. http://dx.doi.org/10.1016/j.jmarsys.2009.10.011

Avis A.M., 1989. A review of coastal dune stabilization in the Cape Province of South Africa. Landscape Urban Plan. 18: 55-68. http://dx.doi.org/10.1016/0169-2046(89)90055-8

Bate G., Ferguson M. 1996. Blowouts in coastal foredunes. Landscape Urban Plan. 34 (3): 215-224. http://dx.doi.org/10.1016/0169-2046(95)00218-9

Bello-Millán F.J., Somoano M., Clavero M., et al. 2015. Evolución histórica del sistema dunar de Valdevaqueros. XIII Jornadas Españolas de Ingeniería de Costas y Puertos. Avilés.

Boletín Oficial del Estado (BOE). 1988. Spanish Shore Act (in Spanish) 29/07/1988: 18762.

Boletín Oficial de la Junta de Andalucía (BOJA) no 135/2001. Declaration of Natural Monuments in Andalucia, 22/11/2001, 18834.

Cabrera L., Alonso I. 2010. Correlation of aeolian sediment transport measured by sand traps and fluorescent tracers. J. Mar. Syst. 80(3): 235-242. http://dx.doi.org/10.1016/j.jmarsys.2009.10.012

Capon R.A. 2006. High resolution studies of the Gibraltar Levanter validated using sun-glint anemometry. Meteorol. Appl. 13(3): 257-265. http://dx.doi.org/10.1017/S135048270600226X

Cooper J.A.G., McLaughlin S. 1998. Contemporary multidisciplinary approaches to coastal classification and environmental risk analysis. J. Coastal Res. 14(2): 512-524.

Davis R.A. Jr., Hayes M.O. 1984. What is a wave-dominated coast? Mar. Geol. 60: 313-329. http://dx.doi.org/10.1016/0025-3227(84)90155-5

del Río L. 2007. Riesgos de erosión costera en el litoral atlántico gaditano. PhD Thesis, Univ. Cádiz, $496 \mathrm{pp}$

del Río L., Gracia J. 2013. Error determination in the photogrammetric assessment of shoreline changes. Nat. Hazards 65(3): 2385-2397. http://dx.doi.org/10.1007/s11069-012-0407-y

del Río L., Plomaritis T.A., Benavente J., et al. 2012. Establishing storm thresholds for the Spanish Gulf of Cádiz coast. Geomorphology 143: 13-23. http://dx.doi.org/10.1016/j.geomorph.2011.04.048

del Valle H.F., Rostagno C.M., Coronato F.R., et al. 2008. Sand dune activity in north-eastern Patagonia. J. Arid Environ. 72(4): 411-422. http://dx.doi.org/10.1016/j.jaridenv.2007.07.011

Domínguez L., Gracia F.J., Anfuso G. 2004. Tasas de avance/ retroceso de la línea de costa mediante morfometría fotogrametrica en el sector Sanlucar de Barrameda-Rota (Cádiz). Rev. Soc. Geol. España 17(1-2): 71-86.

Dorman C.E., Beardsley R.C., Limeburner R. 1995. Winds in the Strait of Gibraltar. Q. J. R. Meteorol. Soc. 121: 1903-1921 http://dx.doi.org/10.1002/qj.49712152807

Fages L., Gómez-Pina G., Navarro M., et al. 2007. Integrated study of alternatives for Valdevaqueros dune area (Tarifa, Spain). Proceed. Int. Conf. Manag. Restoration Coast. Dunes. Santander, Spain, 168-171.

Girardi J.D., Davis D.M. 2010. Parabolic dune reactivation and migration at Napeague, NY, USA: Insights from aerial and GPR imagery. Geomorphology 114(4): 530-541. http://dx.doi.org/10.1016/j.geomorph.2009.08.011

Gómez-Pina G., Muñoz-Pérez J.J., Ramírez J.L. et al. 2002. Sand dune management problems and techniques. J. Coastal Res. SI: 325-332.

Gómez-Pina G., Fages L., Román-Sierra J., et al. 2007. An example of Integrated Coastal Management in Punta Candor (Co. Rota, Spain). In: 1st Int. Conf. on Restoration and Manag. Coastal Dunes, Santander: 1-6.

Gracia F.J., Benavente J. 2000. Geomorfología de la costa atlántica gaditana. In: de Andrés J.R., Gracia F.J. (eds), Geomorfología Litoral. Procesos activos. Spanish Society of Geomorphology,
Monograph 7, Instituto Tecnológico y Geominero de España, Univ. Cádiz, pp. 235-255.

Gracia F.J., Benavente J., Alonso C., et al. 2011. Las dunas del litoral gaditano. In: Sanjaume E., Gracia F.J. (eds.): Las dunas en España. Spanish Society of Geomorphology, pp. 359-384.

Gracia F.J., Nuño T., del Río L., et al. 2013. Valdevaqueros, Cádiz: La difícil gestión de una gran duna móvil. Enseñanza de las Ciencias de la Tierra 21(3): 332-335.

Gutiérrez-Mas J.M., Martín A., Domínguez S., et al. 1991. Introducción a la geologia de la provincia de Cádiz. Serv. Publ. Univ. Cádiz, 315 pp.

Hanson P.R., Arbogast A.F., Johnson W.C., et al. 2010. Megadroughts and late Holocene dune activation at the eastern margin of the Great Plains, north-central Kansas, USA. Aeolian Res. 1: 101-110. http://dx.doi.org/10.1016/j.aeolia.2009.10.002

Hertling U.M., Lubke R.A. 1999. Use of Ammophila arenaria for Dune Stabilization in South Africa and its Current DistributionPerceptions and Problems. Environ. Manag. 24: 467-482. http://dx.doi.org/10.1007/s002679900247

IHM (Instituto Hidrográfico de la Marina). 2010. Anuario de Mareas. San Fernando, Ministerio de Defensa.

Jackson D.W.T., Cooper J.A.G. 2011. Coastal dune fields in Ireland: rapid regional response to climatic change. J. Coastal Res. 64: 293-297.

Jackson D.W.T., Cruz-Avero N., Smyth T., et al. 2013. 3D airflow modelling and dune migration patterns in an arid coastal dune field. J. Coastal Res. SI 65: 1301-1306.

Jackson D.W.T., Cooper J.A.G., Green A.N. 2014. A preliminary classification of coastal sand dunes of KwaZulu-Natal. J. Coastal Res. SI 70: 718-722. http://dx.doi.org/10.2112/SI70-121.1

Jiménez J.A., Maia L.P., Serra J., et al. 1999. Aeolian dune migration along the Ceará coast, north-eastern Brazil. Sedimentology 46(4): 689-701. http//dx doi.org/10.1046/j.1365-3091.1999.00240 x

Levin N., Kidron G.J., Ben-dor E. 2007. A field quantification of coastal dune perennial plants as indicators of surface stability, erosion or deposition. Sedimentology 55(4): 751-772. http://dx.doi.org/10.1111/j.1365-3091.2007.00920.x

Ley C., Navarro-Pons M., Muñoz-Pérez J.J. 2011. Métodos generales de restauración de sistemas dunares. In: Sanjaume Saumell E., Gracia F.J. (eds). Las dunas en España. Pub. Spanish Geomorphology Society.

Maia L.P., Freire G.S.S., Lacerda L.D. 2005. Accelerated dune migration and aeolian transport during El Nino events along the NE Brazilian coast. J. Coastal Res. 21(6): 1121-1126. http://dx.doi.org/10.2112/03-702A.1

Martínez M.L., Gallego J.B., García-Franco J.G., et al. 2006. Assessment of coastal dune vulnerability to natural and anthropogenic disturbances along the Gulf of México. Environ. Conserv. 33 (2): 109-117.

Muñoz-Pérez J.J., Navarro M., Román-Sierra J., et al. 2009. Longterm evolution of a transgressive migrating dune using reconstruction of the EOF method. Geomorphology 112: 167-177. http://dx.doi.org/10.1016/j.geomorph.2009.05.016

Muñoz-Pérez J.J., Román-Sierra J., Navarro-Pons M., et al. 2014. Comments on "Confirmation of beach accretion by grain-size trend analysis: Camposoto beach, Cádiz, SW Spain" by Poizot et al. (2013) Geo-Marine Letters 33(4), Geo-Mar. Lett. 34 (1): $75-78$ http://dx.doi.org/10.1007/s00367-013-0344-0

Navarro M. 2011. Modelización de la evolución morfodinámica de la duna de Valdevaqueros (T.M. Tarifa) mediante la aplicación de Funciones Empiricas Ortogonales a corto, medio y largo plazo. PhD Thesis. Univ. Cádiz.

Navarro M., Muñoz-Pérez J.J., Román-Sierra J., et al. 2011. Assessment of highly active dune mobility in the medium, short and very short term. Geomorphology 129(1-2): 14-28. http://dx.doi.org/10.1016/j.geomorph.2011.01.009

Navarro M., Muñoz-Pérez J.J., Román-Sierra J., et al. 2015. Characterization of wind-blown sediment transport with height in a highly mobile dune (SW Spain). Geol. Acta 13(2): 155-166.

Paskoff R. 2003. La conservation des dunes littorales implique-telle leur stabilisation? L'exemple de la côte atlantique. Natures sciences sociétés 11(3): 288-294.

Plomaritis T.A., Puyana I., Benavente J., et al. 2013. Can grain size trend analysis be used to identify Aeolian sediment transport pathways? The case of Bolonia dune (SW Spain). J. Coastal Res. SI 65: 1325-1330. 
Portz L., Manzolli R.P., Hermanns L., et al. 2015. Evaluation of the efficiency of dune reconstruction techniques in Xangri-lá (Rio Grande do Sul, Brazil). Ocean Coast. Manage. 104: 78-89. http://dx.doi.org/10.1016/j.ocecoaman.2014.12.005

Rodríguez-Santalla I., Sanchez M.J., Montoya I., et al. 2009. Internal structure of the aeolian sand dunes of El Fangar spit, Ebro Delta (Tarragona, Spain). Geomorphology 104 (3-4): 238-252. http://dx.doi.org/10.1016/j.geomorph.2008.08.017

Román-Sierra J., Navarro-Pons M., Muñoz-Pérez J.J., et al. 2004. Ecosistemas dunares en la provincia de Cádiz: Estabilizaciones en Bolonia y Valdevaqueros (Tarifa). Revista de Obras Públicas 3450: 65-76.

Román-Sierra J., Muñoz-Pérez J.J., Navarro-Pons M. 2013. Influence of sieving time on the efficiency and accuracy of grainsize analysis of beach and dune sands. Sedimentology 60(6): 1484-1497. http://dx.doi.org/10.1111/sed.12040

Román-Sierra J., Muñoz-Pérez J.J., Navarro-Pons M. 2014. Beach nourishment effects on sand porosity variability, Coast. Eng. 83: 221-232. http://dx.doi.org/10.1016/j.coastaleng.2013.10.009

Rust I.C., Illenberger W.K. 1996. Coastal dunes: sensitive or not? Landscape and Urban Planning 34, 165-169. http://dx.doi.org/10.1016/0169-2046(95)00232-4

Saye S.E., Pye K., Clemmensen L.B. 2006. Development of a clifftop dune indicated by particle size and geochemical characteristics: Rubjerg Knude, Denmark. Sedimentology 53 (1): 1-21. http://dx.doi.org/10.1111/j.1365-3091.2005.00749.x

Schmeisser R.L., Loope D.B., Wedin D.A. 2009. Clues to the medieval destabilization of the Nebraska Sand Hills, USA, from Ancient Pocket Gopher Burrows. Palaios 24 (11-12): 809-817. http://dx.doi.org/10.2110/palo.2009.p09-037r
Serra J., Riera G., Argullos J., et al. 1997. El transporte eólico en el Delta del Ebro. Evaluación y contribución al modelado litoral. Bol. Geol. Minero 108(4): 477-485.

Silva P.G., Borja F., Zazo C., et al. 2005. Archaeoseismic record at the ancient Román City of Baelo Claudia (Cádiz, south Spain). Tectonophysics 408: 129-146. http://dx.doi.org/10.1016/j.tecto.2005.05.031

Tastet J.P., Pontee N.I. 1998. Morpho-chronology of coastal dunes in Medoc. A new interpretation of Holocene dunes in Southwestern France. Geomorphology 25: 93-109. http://dx.doi.org/10.1016/S0169-555X(98)00035-X

Tsoar H., Blumberg D.G., Stoler Y. 2004. Elongation and migration of sand dunes. Geomorphology 57: 293-302. http://dx.doi.org/10.1016/S0169-555X(03)00161-2

Tsoar H., Levin N., Porat N., et al. 2009. The effect of climate change on the mobility and stability of coastal sand dunes in Ceará State (NE Brazil). Quaternary Res. 71 (2): 217-226. http://dx.doi.org/10.1016/j.yqres.2008.12.001

Willetts B.B., Phillips C.J. 1978. Using Fences to Create and Stabilise Sand Dunes. Coastal Engin. Proceed. 1(16): 2040-2050. http://dx.doi.org/10.1061/9780872621909.125

Williams A.T., Davies P. 2001. Coastal dunes of Wales; vulnerability and protection. J. Coastal Conserv. 7: 145-154 http://dx.doi.org/10.1007/BF02742476

Yao Z.Y., Wang T., Han Z.W., et al. 2007. Migration of sand dunes on the northern Alxa Plateau, Inner Mongolia, China. J. Arid Environ. 70: 80-93. http://dx.doi.org/10.1016/j.jaridenv.2006.12.012

Yizhaq H., Ashkenazy Y., Tsoar H. 2007. Why do active and stabilized dunes coexist under the same climatic conditions? Phys. Rev. Lett. 98(18): 188001. http://dx.doi.org/10.1103/PhysRevLett.98.188001 